UDC 604.6: 613.2

DOI: $10.21668 /$ health.risk/2020.4.10.eng

Research article

\title{
ANALYSIS OF GMO CONTENTS AS A COMPONENT IN RISK-ORIENTED SURVEILLANCE OVER FOOD PRODUCTS SAFETY
}

\section{G.F. Mukhammadieva, A.B. Bakirov, D.O. Karimov, E.R. Kudoyarov, L.Sh. Nazarova, Ya.V. Valova, M.M. Ziatdinova}

Ufa Research Institute of Occupational Health and Human Ecology, 94 Stepana Kuvykina Str., Ufa, 450106, Russian Federation

Control over use of genetically modified products is a vital task within a risk-oriented model for surveillance over food safety products all over the world including the Russian Federation.

Our research goal was to examine domestically manufactured food products in order to determine whether they contained certain regulatory sequences typical for genetically modified organisms.

We applied polymerase chain reaction with hybridization-fluorescent detection in real time mode to examine 77 food products samples; the task was to determine whether they contained DNA enhancer (E-35S) and promoter (P-35S) of S35 sequence belonging to cauliflower mosaic virus, terminator of nopaline synthase gene from Agrobacterium tumefaciens (T-NOS), 35 S enhancer (E-FMV) and promoter (P-FMV) of Figwort mosaic virus, as well as vegetable DNA inducing soya DNA.

When analyzing the extracted DNA, we didn't detect transgenic elements in any samples; however, there were vegetable components reveled in them including $68.8 \%$ samples with soya DNA. We established that some sausages were falsified as they contained vegetable elements. In $15.6 \%$ cases data on a product structure turned out to be false because soya DNA was not listed on consumer package. Our research on determining soya DNA and transgenic elements in food products indicates that soya ingredients have been added into food products in spite of their absence in relevant documents as recipe components.

All the obtained results taken into account, we assume it is necessary to improve control procedures for detecting genetically modified and vegetable components used as ingredients in food products as their falsification can make for changes not only in their consumer properties but also damage consumers' health.

Key words: genetically modified organisms, enhancers, promoter, terminators, polymerase chain reaction, DNA soya, vegetable DNA, falsification, food products safety.

Genetic engineering has been developing intensely over recent years and it has resulted in creation of new selection technologies based on targeted modification in plant genome [1].
Every year plants with genetically modified hereditary properties are produced in larger quantities and more widely applied in agriculture [2]. Genetic modification gives them spe-

(c) Mukhammadieva G.F., Bakirov A.B., Karimov D.O., Kudoyarov E.R., Nazarova L.Sh., Valova Ya.V., Ziatdinova M.M., 2020

Guzel' F. Mukhammadieva - Candidate of Biological Sciences, Senior researcher at the Department for Toxicology and Genetics with The Experimental Clinics for Laboratory Animals (e-mail: ufniimt@mail.ru; tel.: +7 (347) 255-57-48; ORCID: https://orcid.org/0000-0002-7456-4787).

Akhat B. Bakirov - Doctor of Medical Sciences, Professor, Director (e-mail: fbun@uniimtech.ru; tel.: +7 (347) 255-19-57; ORCID: https://orcid.org/0000-0001-6593-2704).

Denis O. Karimov - Candidate of Medical Sciences, Head of the Department for Toxicology and Genetics with The Experimental Clinics for Laboratory Animals (e-mail: karimovdo@gmail.com; tel.: +7 (347) 255-57-48; ORCID: https://orcid.org/0000-0003-0039-6757).

El'dar R. Kudoyarov - Junior researcher at the Department for Toxicology and Genetics with The Experimental Clinics for Laboratory Animals (e-mail: ekudoyarov@gmail.com; tel.: +7 (347) 255-57-48; ORCID: https://orcid.org/0000-0002-2092-1021).

Liliya Sh. Nazarova - Candidate of Medical Sciences, Researcher at the Department for Toxicology and Genetics with The Experimental Clinics for Laboratory Animals (e-mail: lilinaz19@mail.ru; tel.: +7 (347) 255-57-48; ORCID https://orcid.org/0000-0002-9666-5650).

Yana V. Valova - Junior researcher at the Department for Toxicology and Genetics with The Experimental Clinics for Laboratory Animals (e-mail: Q.juk@yandex.ru; tel.: +7 (347) 255-57-48; ORCID: https://orcid.org/0000-0001-6605-9994).

Munira M. Ziatdinova - Junior researcher at the Department for Toxicology and Genetics with The Experimental Clinics for Laboratory Animals (e-mail: munira.munirovna@yandex.ru; tel.: +7 (347) 255-57-48; ORCID: https://orcid.org/ 0000-0002-1848-7959). 
cific properties that increase their resistance to adverse climatic factors, pests, pesticides, and diseases [3, 4]. According to the latest data genetically modified cultures are grown on almost 200 million hectares worldwide [5]. New lines of transgenic plants are created every year in spite of all concerns related to insufficiently examined impacts exerted by genetically modified organisms (GMO) on human health and the environment [6-8]. We should note that at present, according to data provided by the International Service for the Acquisition of Agri-biotech Applications (ISAAA), there are 526 genetically modified (GM) lines of 32 plant species registered all over the world [9]. 27 GM-cultures out of them are allowed to be used in the Russian Federation (15 corn lines, 10 soya lines, 1 beetroot line, and 1 rice line); however, GM-plants can be grown only on test land spots $[10]^{1}$. Nevertheless, we can run across food products on the market, both domestically produced and imported ones, that are made from GMO-containing ingredients $[11,12]$.

Issues related to GM-products safety and control over their application are being discussed all over the world [13-15]. Thus, a threshold level for food GM-products marking in Japan amounts to $5 \%$; in Australia and New Zealand, $1 \%$; and in the EU countries, $0.9 \%$ [16-18]. The RF legislation also stipulates that population should be informed about GMO contents in products [19]. In Russia alterations into the Technical Regulations on food products marking came into force on December 26, 2018. Should such products be manufactured with the use of GMO, then a «GMO» sign is made on their package close to a unified sigh for products allowed to be distributed on the Eurasian Economic Union market; both signs are to be of the same size and shape. This special GMO marking is to be put on all products with GM-components in them exceeding $0.9 \%^{2}$.
Meat and food products made of processed meat are an essential part in food rations consumed by people in Russia. GM-soya is a frequently occurring source of genetically modified components in meat products as there is hardly an enterprise that makes sausage and manages without it. However, not the fact itself that vegetable protein has been added is important but absence of any data on it. Surveillance over adherence to scientifically substantiated recipes that involves determining raw components in finished meat products often reveals falsifications, both regarding their contents and their quality as well $[20,21]$.

A most vital task related to providing proper quality and safety of food products is to develop, implement, and update systems for control over raw materials and finished products using highly efficient analysis techniques. Polymerase chain reaction (PCR), including that performed in real-time mode, is among such techniques applied within controlling procedures and GMO safety assessment $[22,23]$.

Our research goal was to examine domestically produced food products and determine whether they contained regulatory sequences typical for genetically modified organisms; the research was aimed at improving risk-oriented surveillance over food products safety.

Data and methods. Overall, we selected 77 food products for determining genetically modified ingredients in them; they were 73 meat products (sausage, ham, and pate); 2 soya products (soya milk and soya cheese), 1 soya texture that was a component in a dressing for instant macaroni product made of dried vegetables, and 1 bread sample that contained soya flour. All the examined samples were homogenized. DNA was extracted out of homogenized samples with «DNK-sorb-S-M» kits (Rospot-

\footnotetext{
${ }^{1}$ On making alterations into certain legislative acts in the Russian Federation regarding improvements of the state regulation in the sphere of genetic engineering: The Federal Law No. 358-FZ issued on July 03, 2016. KODEKS: an electronic fund for legal and reference documentation. Available at: http://docs.cntd.ru/document/420363719 (21.04.2020) (in Russian).

${ }^{2}$ CU TR 022/2011. Food products and their marking: The Customs Union Technical Regulations (last edited on September 14, 2018). KODEKS: an electronic fund for legal and reference documentation. Available at: http://docs.cntd.ru/document/902320347 (29.04.2020) (in Russian).
} 
rebnadzor's Scientific Research Center, Russia) and «MagnoPrime FITO» (NekstBio LLC, Russia).

PCR with hybridization-fluorescence detection was performed in real time mode on Rotor-Gene Q (Qiagen, Germany) and CFX96 (Bio-Rad, the USA) amplifiers. We performed our research with reagent kits produced by Rospotrebnadzor's Scientific Research Center; «AmpliSens GM Plant-1-FL» kit was used to determine DNA fragments of an enhancer (E-35S) and promoter (P-35S) in a sequence belonging to $35 \mathrm{~S}$ cauliflower pattern virus; gene terminator of nopaline-synthase from Agrobacterium tumefaciens (T-NOS); enhancer (E-FMV) and promoter (P-FMV) of $35 \mathrm{~S}$ fig-wort pattern virus. «AmpliKvant GM soya-FL» was used to quantitatively determine GM-soya lines that had an enhancer (E-35S) or promoter $(\mathrm{P}-35 \mathrm{~S})$ in a sequence belonging to $35 \mathrm{~S}$ cauliflower pattern virus in their genome. Besides, performing an analysis with «AmpliSens GM Plant-1-FL» test system, we determined plant endogenous control, that is, a gene that was specific for plant genome (both transgenic and non-transgenic); it was the evidence that plant DNA occurred in an examined sample. «AmpliKvant GM soya-FL» kit allowed revealing soya DNA occurrence basing on use of soya endogenous control.

Amplification was performed with RotorGene Q device as per the following procedure: $95^{\circ} \mathrm{C}$ for 15 minutes, 1 cycle; $95^{\circ} \mathrm{C}$ for 10 seconds, $59^{\circ} \mathrm{C}$ for 1 minute, 45 cycles. The procedure for CFX96 device was as follows: $95^{\circ} \mathrm{C}$ for 15 minutes, 1 cycle; $95^{\circ} \mathrm{C}$ for 15 seconds, $59^{\circ} \mathrm{C}$ for 1 minute, 42 cycles. FAM, HEX, ROX и Сy5 phosphors were used as fluorescent compounds applied for determining specific sequences. We analyzed accumulation curves for fluorescent signals as per each detection channel using program software installed on the devices. Results were interpreted basing on occurrence (or absence) of an intersection between fluorescence curve on a relevant channel with threshold curve that determined occurrence (or absence) of threshold cycle $\mathrm{Ct}$ value for this sample. The test was considered valid in case correct results were obtained for controls of DNA extraction and amplification. Data wee statistically processed with Microsoft Excel 2010.

Results and discussion. We analyzed 77 domestically produced food products. Meat products accounted for the biggest share of them, $94.8 \%$. Having examined marking on 77 food products, including meat and soya ones, we didn't manage to find any data on GMO occurrence in any of them. Having analyzed extracted DNA, we revealed that all samples didn't contain any fragments of enhancer (E-35S) or promoter $(\mathrm{P}-35 \mathrm{~S})$ in a sequence belonging to $35 \mathrm{~S}$ cauliflower pattern virus, gene terminator of nopaline-synthase from Agrobacterium tumefaciens (T-NOS), as well as enhancer (E-FMV) or promoter (P-FMV) $35 \mathrm{~S}$ of $35 \mathrm{~S}$ fig-wort pattern virus that frequently occurred in GM-plants. Threshold cycle values were not determined as per three channels (Cy5, FAM, and ROX). But still, vegetable components were detected in all samples. The Figure below shows accumulation curves for fluorescent signal obtained for five food product samples as per HEX channel; these curves allow us to state that the samples contain plant DNA (Figure).

At the next stage we examined food products in order to reveal soya DNA and regulatory sequences that were typical for GMO. To do that, we used «AmpliKvant GM soya-FL» reagent kit that allowed determining both GM-components and falsification with soya ingredients. Having analyzed the selected food products, we didn't find any transgenic constructions in them. But still, $68.8 \%$ analyzed samples contained soya DNA. However, data on soya additives was absent in $15.6 \%$ cases and it means such products were falsified. Their manufacturers used soya raw materials which were not listed on their labels as components in a finished product. We should note that all such non-conformities were revealed for sausages.

Conclusion. Our examination performed on food products didn't reveal any plant GMO but instead we found plant DNA fragments 


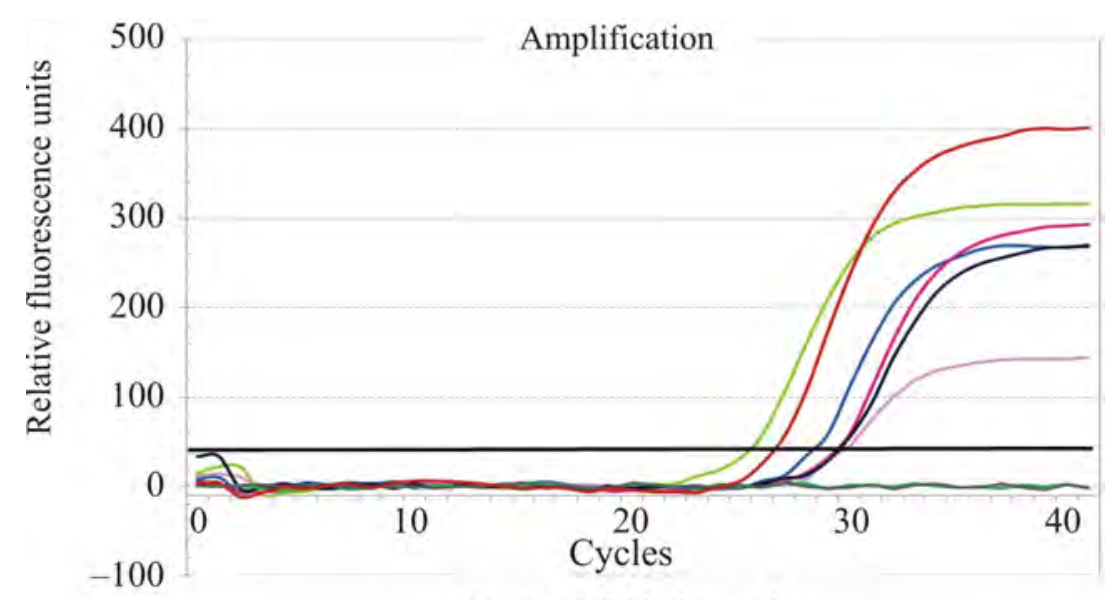

As per HEX channel
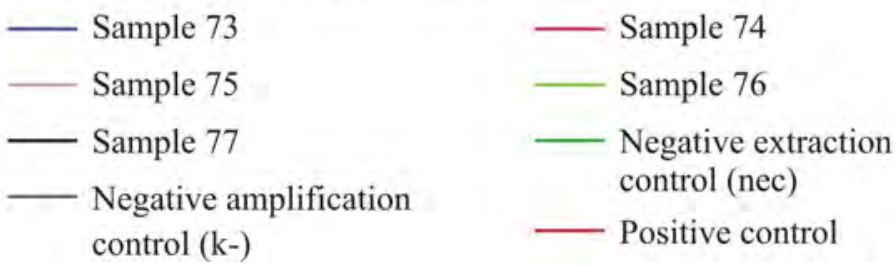

Figure. Accumulation curves for fluorescent signal obtained for food products samples No. 73-77 as per HEX channel with CFX96 device

including $68.8 \%$ samples that contained soya DNA. Soya was not listed among components on consumer package in $15.6 \%$ cases and it is informational falsification. Results obtained via determining DNA soya contents and transgenic construction elements in food products indicate that additional soya ingredients were included into them without being declared in relevant documents as recipe components.

Therefore, our analysis allowed revealing that data listed on food products labels are not always credible as regards ingredients. These cases are crude violation of the Federal Law «On consumer rights protection» as regards providing customers with reliable data. Absence of data on components which are in- cluded into a food product on its label does not conform to requirements fixed in the Customs Union Technical Regulations TR TS 022/2011 «Food products and their marking». Taking these results into account, it is necessary to improve control over occurrence of GMO and plant components used as ingredients in food production since food products falsification can lead not only to changes in their consumer properties but also cause damage to consumers' health.

Funding. The research was not granted any sponsor support.

Conflict of interests. The authors declare there is no any conflict of interests.

\section{References}

1. Nogué F., Mara K., Collonnier C., Casacuberta J.M. Genome engineering and plant breeding: impact on trait discovery and development. Plant. Cell. Rep., 2016, vol. 35, no. 7, pp. 1475-1486. DOI: $10.1007 / \mathrm{s} 00299-016-1993-\mathrm{z}$

2. Kamthan A., Chaudhuri A., Kamthan M., Datta A. Genetically modified (GM) crops: milestones and new advances in crop improvement. Theor. Appl. Genet., 2016, vol. 129, no. 9, pp. 1639-1655. DOI: $10.1007 / \mathrm{s} 00122-016-2747-6$

3. Bailey-Serres J., Parker J.E., Ainsworth E.A., Oldroyd G.E.D., Schroeder J.I. Genetic strategies for improving crop yields. Nature, 2019, vol. 575, no. 7781, pp. 109-118. DOI: $10.1038 / \mathrm{s} 41586-019-1679-0$ 
4. Van Esse H.P., Reuber T.L., Van der Does D. Genetic modification to improve disease resistance in crops. New. Phytol., 2020, vol. 225, no. 1, pp. 70-86. DOI: 10.1111/nph.15967

5. Brief 54: Global status of commercialized biotech/GM crops in 2018. Biotech crop continue to help meet the challenges of increased population and climate change. ISAAA, 2018. Available at: https://www.isaaa.org/resources/publications/briefs/54/default.asp (21.04.2020).

6. Status of dossiers. European Union Reference Laboratory for GM Food and Feed, 2020. Available at: https://gmo-crl.jrc.ec.europa.eu/StatusOfDossiers.aspx (21.04.2020).

7. GM Approval Database. ISAAA, 2020. Available at: http://www.isaaa.org/gmapprovaldatabase/ (21.04.2020).

8. Kumar K., Gambhir G., Dass A., Tripathi A.K., Singh A., Jha A.K., Yadava P., Choudhary M., Rakshit S. Genetically modified crops: current status and future prospects. Planta, 2020, vol. 251, no. 4, pp. 91. DOI: 10.1007/s00425-020-03372-8

9. GM Approval Database. GM Crop Events List. ISAAA, 2020. Available at: http://www.isaaa.org/ gmapprovaldatabase/eventslist/default.asp (21.04.2020).

10. Baza dannykh GMO [GMO database]. GenBit, 2020. Available at: https://www.genbitgroup.com/ru/gmo/gmodatabase/ (21.04.2020) (in Russian).

11. Samoilov A.V., Samoilova E.A. A study of the food market of Moscow and Moscow region for the presence of GMO products. Sinergiya Nauk, 2018 no. 28, pp. 1390-1396 (in Russian).

12. Dolgikh O.V., Krivtsov A.V., Mazunina A.A. Osobennosti kontaminatsii produktov detskogo pitaniya geneticheski-modifitsirovannymi organizmami [Peculiarities of baby food contamination with genetically modified organisms]. Aktual'nye voprosy analiza riska pri obespechenii sanitarnoepidemiologicheskogo blagopoluchiya naseleniya i zashchity prav potrebitelei: materialy IX Vserossiiskoi nauchno-prakticheskoi konferentsii s mezhdunarodnym uchastiem, Perm, 2019, pp. 317-321 (in Russian).

13. Yang Y.T., Chen B. Governing GMOs in the USA: science, law and public health. J. Sci. Food. Agric., 2016, vol. 96, no. 6, pp. 1851-1855. DOI: 10.1002/jsfa.7523

14. Rostoks N., Grantiņa-Ieviņa L., Ieviņa B., Evelone V., Valciņa O., Aleksejeva I. Genetically modified seeds and plant propagating material in Europe: potential routes of entrance and current status. Heliyon, 2019, vol. 15, no. 2, pp. e01242. DOI: 10.1016/j.heliyon.2019.e01242

15. Slot M.M., Van de Wiel C.C.M., Kleter G.A., Visser R.G.F., Kok E.J. The assessment of field trials in GMO research around the world and their possible integration in field trials for variety registration. Transgenic Res., 2018, vol. 27, no. 4, pp. 321-329. DOI: 10.1007/s11248-018-0076-Z

16. Milavec M., Dobnik D., Yang L., Zhang D., Gruden K., Zel J. GMO quantification: valuable experience and insights for the future. Anal. Bioanal. Chem., 2014, vol. 406, no. 26, pp. 6485-6497. DOI: $10.1007 / \mathrm{s} 00216-014-8077-0$

17. Davison J., Ammann K. New GMO regulations for old: Determining a new future for EU crop biotechnology. GM Crops Food, 2017, vol. 8, no. 1, pp. 13-34. DOI: 10.1080/21645698.2017.1289305

18. Borges B.J.P., Arantes O.M.N., Fernandes A.A.R., Broach J.R., Fernandes P.M.B. Genetically Modified Labeling Policies: Moving Forward or Backward? Front. Bioeng. Biotechnol., 2018, no. 6, pp. 181. DOI: 10.3389/fbioe.2018.00181

19. Muratov A.A., Moskovenko N.V., Tikhonov S.L., Tikhonova N.V., Kurdyumov A.V. Normativno-pravovye aspekty regulirovaniya geneticheski modifitsirovannykh produktov na territorii tamozhennogo soyuza [Legal aspects in regulation over genetically modified products on the Customs Union territory]. Agroprodovol'stvennaya politika Rossii, 2017, vol. 63, no. 3, pp. 78-83 (in Russian).

20. Lebedeva S.N. Analiz rynka proizvoditelei i opredelenie transgennoi soi v kolbasnykh izdeliyakh i polufabrikatakh, realizuemykh $\mathrm{v}$ gorode Ulan-Ude [Analysis of manufacturers market and transgenic soya determination in sausages and semi-finished products sold in Ulan-Ude]. Sovremennye tendentsii razvitiya nauki i tekhnologii, 2016, no. 2-1, pp. 54-57 (in Russian).

21. Guzeeva A.A., Kapitova I.A., Pal'tsev A.A. Product adulteration in meat products. Nauchnye issledovaniya - sel'skokhozyaistvennomu proizvodstvu: materialy Mezhdunarodnoi nauchnoprakticheskoi konferentsii, Orel, 2018, pp. 293-296 (in Russian). 
22. Grohmann L., Keilwagen J., Duensing N., Dagand E., Hartung F., Wilhelm R., Bendiek J., Sprink T. Detection and identification of genome editing in plants: challenges and opportunities. Front. Plant. Sci., 2019, vol. 10, pp. 236. DOI: 10.3389/fpls.2019.00236

23. Fraiture M.A., Herman P., Taverniers I., De Loose M., Deforce D., Roosens N.H. Current and new approaches in GMO detection: challenges and solutions. Biomed. Res. Int., 2015, vol. 2015, pp. 392872 . DOI: $10.1155 / 2015 / 392872$

Mukhammadieva G.F., Bakirov A.B., Karimov D.O., Kudoyarov E.R., Nazarova L.Sh., Valova Ya.V., Ziatdinova M.M. Analysis of GMO contents as a component in risk-oriented surveillance over food products safety. Health Risk Analysis, 2020, no. 4, pp. 93-98. DOI: 10.21668/health.risk/2020.4.10.eng

Received: 14.05 .2020

Accepted: 11.11.2020

Published: 30.12.2020 